\title{
高強度セラミックスのノッチドビーム法による破壊勒性
}

\author{
松野外男・若井史博 - 岡田正見* - 奥田博 \\ $\left(\begin{array}{l}\text { 名古屋工業技術試験所 } \\ \text { 高丘工業 }(\text { 株) }\end{array}\right.$
}

ノッチドビーム (SENB) の曲げ試験によって, 各種高強度セラミックス材料の破壊鞋性を求め, また 2 次元光弹性実験によってノッチドビーム内の応力分布を調べて, 試験条件の影響を検討した．

その結果試験条件の中でノッチの幅の効果が最む大きく、ノッチ深さの影響がこれに次ぎ，炭化 ケイ素などでは試験スパンの効果が認められた。

また超音波パルスエコー法によってこれらの材料の弾性定数を求め, これと $K_{\mathrm{Ic}}$ の測定值から エネルギー解放率 $g_{\mathrm{Ic}}$ を算出した。 その結果で泣 $\sigma_{\mathrm{b}}$ 及び $K_{\mathrm{Ic}}$ の最も大きい HPSN が $g_{\mathrm{Ic}}$ も 大さく, HPSiC は最小であり破壞しやすさの程度が示された。

$K_{\text {Ic }}$ の值は，ノッチ幅が広くスパンが小さい場合及びノッチの深い場合に破壞待重の増大に伴っ て大きくなり， $5 \times 5 \mathrm{~mm}$ 断面の試験片で最む小さい $K_{\mathrm{Ic}}$ が各材料ともに得られたのは，ノッチの 幅が小さく，气の梁さはビーム高さの $1 / 4$ で，スパンについては $40 \mathrm{~mm}$ の大きい場合であった. $K_{\text {Ic }}$ の增大しやすい材料はヤング率と曲げ強さの比が大きいものが多い。(1981 年6月23 日受付)

\section{Fracture Toughness of High Strength Ceramics by Notched Beam Test}

\author{
Yosoo MATSUNO, Fumihiro WAKAI, Masami OKADA* and Hiroshi OKUDA \\ $\left(\begin{array}{l}\text { Government Industrial Research Institute, Nagoya } \\ \text { 1, Hirate-cho, Kita-ku, Nagoya-shi } 462 \\ \text { Takaoka Kogyo Co., Ltd. }\end{array}\right)$
}

Ceramics are typical brittle materials, and fracture occurs owing to crack initiation caused by stress. Therefore, it is very important to measure the fracture toughness for evaluating the mechanical properties of ceramics. In this work, the fracture toughness of various kinds of ceramics were measured by the bending fracture of notched beams, and also the effect of testing conditions were examined from the stress-distribution of two dimensional photoelasticity experiment with epoxy-resin models. As a result, the notch depth was an effective factor on the $K_{\text {Ic }}$ value, and the notch width was the most effective one. The effect of testing span was also recognized in the test of silicon carbide. And energy release ratio $g_{\text {Ic }}$ is calculated from the obtained $K_{\text {Ic }}$ value and experimental elastic constant of ceramics which was measured by means of ultrasonic pulse echo method. HPSN shows the biggest value of $g_{\text {Ic }}$ from 160 to $220 \mathrm{~J} / \mathrm{m}^{2}$ whereas the $g_{\text {Ic }}$ of HPSiC was the smallest value $33 \mathrm{~J} / \mathrm{m}^{2}$, and this result indicates that the latter material fracture easily. In general, the $K_{\text {Ic }}$ values of ceramics increase as the width of notch become larger, the testing span smaller, and the depth of notch larger. It is because these factors mentioned above increase the fracture load relatively. In the three-point bending test, the smallest value of $K_{\text {Ic }}$ for ceramics was obtained from the testing condition in the notch width and depth of 0.3 and $1.25 \mathrm{~mm}$, the testing span of $40 \mathrm{~mm}$, and specimen size of $5 \times 5 \times 60 \mathrm{~mm}$ long, in this study. The ceramic materials, the $K_{\text {IC }}$ values of which are liable to increase, have larger values of $E / \sigma_{\mathrm{b}}$, and this result showed that the elastic properties gave the effect on the measurement of $K_{\text {Ic }}$ values for ceramics.

[Received June 23, 1981]

Key-words : Fracture toughness, Notched beam test, Energy release ratio, Ceramics, Silicon nitride, Silicon carbide, Alumina 


\section{1. 緒言}

構造材料として注目される各種高強度セラミックス材 料は, その材料力学的強度だけでほなくぜい性破䘫に対 する抵抗性が大きいことが要求され，破壊鞇性值の大き さが重視される．したがってセラミック材料の評価にお いても, 破壞勒性の測定が破壞力学的手法として必須の 条件であり，種々の材料及び方法について報告がある。

ノッチドビーム (SENB) 法による破壞勒性の測定は, 各種のダイヤモンド圧子の圧入による微小き裂法に対し て，大型き裂による測定法の一つであるが，曲げ強さ試 験の手法を用いて行うことができること，均質な鏡面が 得られず微小き裂法による測定が困難な材料にも適用で きるなどの利点がある．この報告ではノッチドビーム法 によって，3 点曲げ試験に対する各種高強度セラミック ス材料の破壞靱性を測定するとともに，試験条件による 応力分布の 変化等を 2 次元光弾性実験などから 検討し て, 最適条件について考察した。

またこれらの祆料のヤング率及びポアソン比を測定し て, 破壞勒性の測定值からエネルギー解放率を求的て, 各材料の特性を比較した。

\subsection{2 次元光弾性実験}

\section{2. 実験}

ノッチドビームの曲げ試験による破壞勒性測定の際 に, 試験片内部に生ずる応力の大きさと分布状態を求 め, 試験片の高さ, ノッチの幅及び深さ, 荷重点及び支 持点の曲率半径, 試験スパン, 及び 3 点負荷, 4 点負荷 等の試験条件の影響を調べるために，エポキシ樹脂模型 による光弾性実験を行った。セラミックス材料は破壊に 至るまでほとんど塑性変形が無く, 弾性体として取り扱 らことができるから，エポキシ樹脂の弾性体模型に置き 換えて応力分布を求める。

光弾性モデルの大きさは, 破壊勒性測定用試験片の 4 倍とし, 使用したエポキシ樹脂板の厚さ (d) は 6 及び $10 \mathrm{~mm}$ で, 幅 (b) $20 \mathrm{~mm}$, 長さ $\left(L_{\mathrm{T}}\right)$ 約 $200 \mathrm{~mm}$ に 切り出し, 機械加工及び手加工によって残留応力が残ら ないように注意して加工し, 先端半径 0.8 及び $1.6 \mathrm{~mm}$ のノッチを施した後に, 電気炉で $120^{\circ} \mathrm{C}$ まで加熱し, $3 \mathrm{~h}$ 保持してから $2.5^{\circ} \mathrm{C} / \mathrm{h}$ で $40^{\circ} \mathrm{C}$ まで徐冷して以後放 冷した.

使用したエポキシ樹脂板の光弾性感度は, 圧縮試験に よって検定し，板の厚さが $t \mathrm{~mm}$, 幅が $d \mathrm{~mm}$ で，等色 線の縞次数 $N$, 荷重 $P \mathrm{kgf}$ で, 応力 $\sigma \mathrm{kgf} / \mathrm{mm}^{2}$ のと き， $\alpha=N / \sigma \cdot t=d \cdot N / P(\mathrm{~mm} / \mathrm{kgf})$ として求めた.

3 点及び 4 点曲げ試験はインストロン材料試験機を用 いて行い, 曲げ試験器具の前後に簡易偏光装置の偏光板 を置き, 光弹性モデルに発生する引っ張り応力による等 色縞の次数とその時の荷重から, 先に検定した光弾性感
度を用いて曲げ応力との関係を求めた．等色線図の撮影 は, 一眼レフ $35 \mathrm{~mm}$ カメラに接写レンズと拡大ファイ ンダーを組み合わせて，観察しつつ行い，単色フィルタ ーとしては $\lambda=5461 \AA$ の濃緑色のものを使用した.

\section{2 ノッチドビーム法による破壊鞄性の測定}

この実験に用いたセラミックス材料は, 焼結アルミナ $\left(\mathrm{SAl}_{2} \mathrm{O}_{3}\right)$, 反応焼結窒化ケイ素 $(\mathrm{RBSN})$, 常圧焼結窒化 ケイ素 (SSN)，及びホットプレス窒化ケイ素 (HPSN) と, 反応焼結炭化ケイ素 (RBSiC) 及びホットプレス崖 化ケイ素 (HPSiC) でいずれも市販品である.

試験片の寸法は，実用的な大きさを考慮して試験片の 高さ $(d)$, 幅 $(b)$, 長さ $\left(L_{\mathrm{T}}\right)$ は $5 \times 5 \times 30 \mathrm{~mm}$ 及び 5 $\times 5 \times 60 \mathrm{~mm}$ とし，支点間距離 $(L)$ が 20 及び $40 \mathrm{~mm}$ のときに L/d が4及び 8 になるようにした.

試験片の加工はアルミナ以外の材料は難削材であるた め, まず素材から厚さ約 $0.5 \mathrm{~mm}$ のダイヤモンドソー によって, マイクロクラックが発生しないように, 切り 込々量 1 2 $\mathrm{mm}$, 切断速度 $20 \mathrm{~mm} / \mathrm{min}$ 程度で切り出 し,その両面を \#80, \#200,\#400のダイヤモンド砥石に よって平面研削仕上げを行った．粗研削及び仕上げ研削 の切り込み量注 $8 \mu \mathrm{m}$ 及び $3 \mu \mathrm{m}$ である.この加工の繰 り返しによって得られた試験片に, 先端半径約 0.15 及 び $0.4 \mathrm{~mm}$ のダイヤモンドソーを用いてノッチ加工を 行った.ノッチ深さは試験片の高さの $1 / 10,1 / 4$ 及び $1 / 2$ の 3 段階とした. 加工に用いたダイヤモンドソーの先端 は GC 砥石を用いて半円形になるように修整し，試験片 のノッチ先端の形状は投影機によって調べた.

図1に SENB 曲げ試験の慨要と試験条件に対する記 号を示した. 3 点曲げ試験はインストロン試験機を用い て行い，荷重点及び支持点に注半径 $2 \mathrm{~mm}$ の焼入社鋼の ローラーを用い, 試験スパンは 20 及び $40 \mathrm{~mm} の 2$ 段階 とした。クロスヘッド速度 $0.05 \mathrm{~mm} / \mathrm{min}$ で荷重を加え たが，これは試験片の高さが $5 \mathrm{~mm}$ で試験スパンが 20 及び $40 \mathrm{~mm}$ のときに，ひずみ速度が 6.25 及び 1.56 $\times 10^{-5} \mathrm{strain} / \mathrm{s}$ に相当する.

破壊鞋性は Brown と Srawley ${ }^{1)}$ が示した係数 Y に

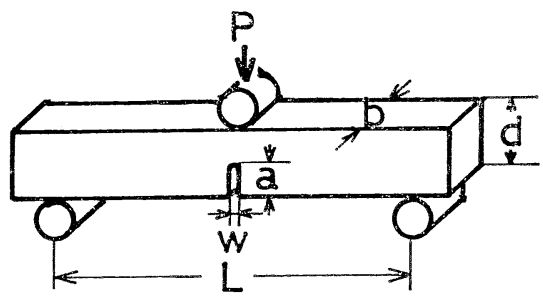

Fig. 1. Schematic diagram of SENB 3-point bending test.

$P:$ Load, $d:$ Specimen height, $b:$ Specimen width, $L:$ Span length, $a:$ Notch depth, $w$ : Notch width 
Table 1. Y Coefficient ${ }^{1}$.

$$
Y=A_{0}-A_{1}(a / d)+A_{2}(a / d)^{2}-A_{3}(a / d)^{3}+A_{4}(a / d)^{4}
$$

\begin{tabular}{|l|c|ccccc|}
\hline & $\mathrm{L} / \mathrm{d}$ & $\mathrm{A}_{0}$ & $\mathrm{~A}_{1}$ & $\mathrm{~A}_{2}$ & $\mathrm{~A}_{3}$ & $\mathrm{~A}_{4}$ \\
\hline Pure bending & & 1.99 & 2.47 & 12.97 & 23.17 & 24.80 \\
3 pt.bending & 8 & 1.96 & 2.75 & 13.66 & 23.98 & 25.22 \\
& 4 & 1.93 & 3.07 & 14.56 & 25.11 & 25.80 \\
\hline
\end{tabular}

対する解を用いて，破壊荷重及びノッチ深さ $a$ などと の関倸から次式によって求めた。

$$
K_{\mathrm{Ic}}=\sigma \cdot a^{1 / 2} \cdot Y=\left(3 L P / 2 b d^{2}\right) \cdot a^{1 / 2} \cdot Y
$$

$Y$ については表 1 に示した。試験片の外形寸法はマ グネスケールを用いて測定し，またノッチの深さはノッ チ加工後に投影機によって測定した.

セラミックス材料の弾性定数の測定は, $10 \mathrm{MHz}$ の超 音波によるパルスエコー法を用いて行った。

\section{3. 実験結果と考察}

\subsection{2 次元光弾性実験結果}

実験に使用したエポキシ樹脂板の光弾性感度の検定値 は,インストロン試験機による圧縮試験によって, 9 次 までの等色線汇対応する荷重を測定した結果から，厚さ $t$ が $6 \mathrm{~mm}$ 及び $10 \mathrm{~mm}$ のものについて，それぞれ 0.95 及び $1.06 \mathrm{~mm} / \mathrm{kg}$ であった。

光弾性モデルの等色線は, 荷重によって発生した二つ の主応力 $\alpha_{1}$ と $\alpha_{2}$ の差が等しい点及びこれの整数倍の 值になる点を示すもので， $\left(\sigma_{1}-\sigma_{2}\right)=\alpha t$ の関係で表され る。しかし自由端では直接に一つの主応力の值を示し， その方向注等色線に垂直である. 更に前述の光弹性感度 と等色線の次数から引っ張り応力あるいは圧縮応力を定 量的に求めることができる. 光弹性実験モデルの寸法は セラミックス試験片の 4 倍で, 試験スパンの $80 \mathrm{~mm}$ 及び $160 \mathrm{~mm}$ は，七ラミックス材料試験では $20 \mathrm{~mm}$ 及び 40 $\mathrm{mm}$ に相当する.

光弾性実験に上る応力分布の観察からは，次のような 結果が得られた．図 2 の等色線図はいずれも引っ張り応 力によって 5 次の等色線が発生した時の状態を示すもの で, 試験条件として下方及び上方スパン $L$ 及び $l$, 荷重 点及び支持点のローラーの半径 $r$, ノッチ幅 $w$, 及びノッ チ深さ $a$ と試験片の高さ $d$ との比 $a / d$ を付記した. $P / N$ は等色線次数 1 次当たりの荷重 $\mathrm{kgf}$ で, この值は 一つの試験条件について，6次線の発生するまでの測定 を各 3 回繰り返して, 測定值による1次の実験式から求 めた。

図 2 (a) 及び図 2 (b) は L/d が4 の場合にお汀る, 3 点負荷及び 4 点負荷による曲げ試験の際の, 試験片中 での応力分布の状態を示す.いずれも中央の中立軸から 上方に圧縮応力部分, 下方には 1 5 次の引っ張り応力
部分が示されている. 図 2 (a) の 3 点負荷の場合には, 中立軸の応力の存在しない部分が不明瞭で, 中央の小さ い三角形の上方の二辺は圧縮応力, 底辺は引っ張り応力 の1次線である。これに対して 4 点負荷では図 2 (b) の ように，圧縮及び引っ張り応力による等色線は，中央に 明瞭に現れた中立軸に平行に順次配列する．この場合同 じ引っ張り応力が発生するためには，3点負荷の場合の 2 倍の荷重となるため, 荷重点及び支持点での圧縮応力 の次数が高い. 3 点夐荷の場合ではスパンを大きくした 場合には, 図 $2(\mathrm{~g})$ に示したように引っ張り忘力の分布 は 4 点負荷の場合に近似している.

試験片に対するノッチの効果はその先端に㦄力を集中 させるが，応力集中係数は Neuber の式の条件よりも 切欠き深さが大きいために, $a / d=1 / 4$ 付近が最大となる 傾向が見られる2). 図 2 (c) 及び図 2 (d) は, 細以ノッ チの効果を示すもので, 図 2 (c)の 3 点負荷のときには; ノッチ先端から 荷重点の間に 比較的長いせん断応力 0 の黒色の部分が見られる.図 2 (d) の 4 点負荷の場合に は，荷重点からノッチ先端に向から短い中立蟿の黒い部 分と, 複雑な応力こう配が認められる。いずれの場合に もノッチ先端に二つに枝分かれした形で, 強い引っ張り 応力が現れるのが特徵であり, 荷重点等の圧縮店力も局 部に集中している.ノッチ幅が広い場合は, 引っ張り応 力の等色縞がノッチの先端を覆う形で順次発生し, 図 2 （e）の 3 点負荷の拡大写真及び，図 2 (d) の 4 点負荷の 等色線図のような応力分布が見られる。これらのノッチ が深い条件では，ノッチ深さが $1 / 4$ の場合上異なって, 引っ張り応力の 1 次線が底辺まで下らないで, 圧縮応力 の1次線と上方の中立軸部分で接合する，ノッチドビー ムにおいては，ノッチの先端付近から底辺に向かって広 がる黒色の応力のない部分が見られ，スリット形のノッ チでもVノッチと同様の効果であることを示している.

試験スパンが長くなると図 2 (i) の 3 点負荷及び図 2 (h), 図 2 (j) の 4 点負荷の例に見られるように, いずれ の場合む荷重点及びノッチ先端付近での急な応力こう配 が緩和されて, 力点間の距離が短くて拘束性の高い場合 と比較して, 良い試験条件であると考えられる. 3 点負 荷と 4 点負荷試験とを比較すると, 3 点負荷で注試験荷 重が小さく, 試験片内の圧縮及び引っ張り応力の分布が 単純なこと， セッティングに起因する応力分布の異常が 少ないことが認められた.

\section{2 セラミックスの破壊勒性測定結果}

$K_{\mathrm{Ic}}$ 測定陚料については，その性質を知る目的で X 線回折による結晶の種類の同定，蛍光X線による微量元 素の検出, かさ密度及びロックウェル硬さの測定を行っ た. また弾性定数は $10 \mathrm{MHz}$ の超音波の縦波及び横波 の試料中での 速度を位相比較法によって求め, ヤング 率, ポアソン比等を算出した。曲げ強さについては, 破 
壊鞋性の 測定に用いた 試験片と同じ寸法の， $5 \times 5 \times 30$ $\mathrm{mm}$ 及び $60 \mathrm{~mm}$ のものを用いて，スパン $20 \mathrm{~mm}$ 及び $40 \mathrm{~mm}$ で 3 点曲げ試験によって測定した。これらの值 の既略を表 2 に示した。

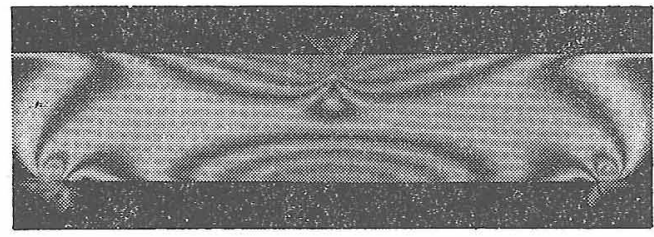

(a) 3-pt. $L: 80, r: 4$, ald $: 0, P / N: 3.44$

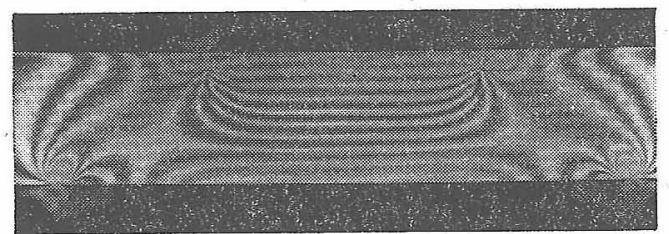

(b) 4-pt. $L: 80, l: 40, r: 4$, ald $: 0, P / N: 7.13$

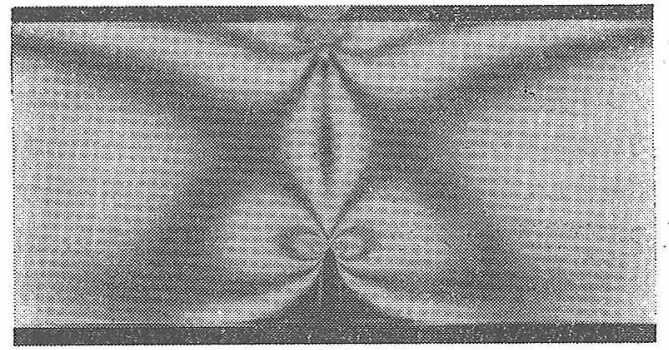

(c) 3-pt. $L: 80, r: 4, w: 1.2$, ald $: 1 / 4, P / N: 1.13$

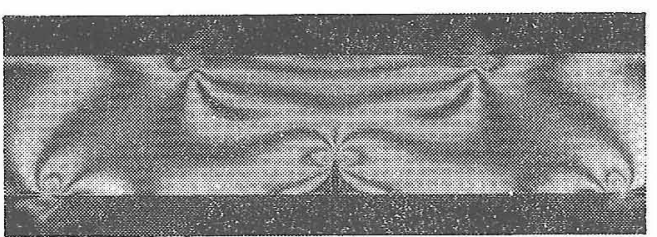

(d) 4-pt. $L: 80, l: 40, r: 4, w: 0.3$, ald $: 1 / 4$, $P / N: 2.49$

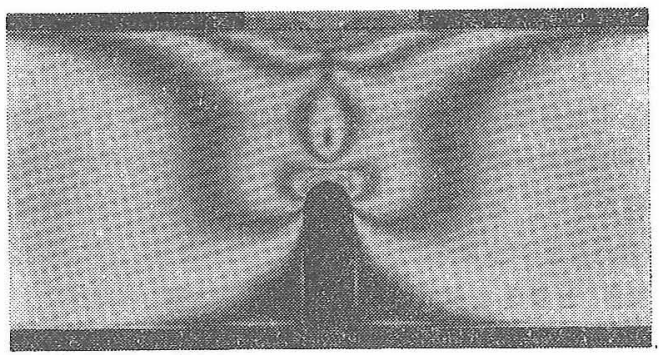

(e) 3-pt. $L: 80, r: 4, w: 3.2$, a/d $: 1 / 2, P / N: 0.69$
セラミックスの SENB 曲げ試呀による破壊鞄性の測 定については，Srawley が解析について仮定したような 体積 0のき裂の条件と，ダイヤモンドソーによるノッ チ先端の条件との差異について多くの議論があり，

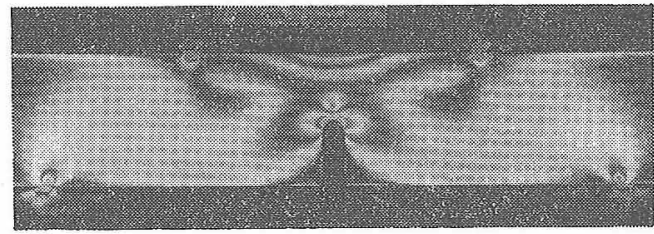

(f) 4-pt. $L: 80, l: 40, r: 4$, re:3.2, ald: $1 / 2$, $P / N: 1.40$

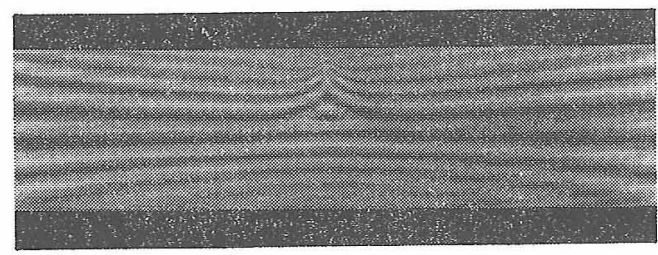

(g) 3-pt. $L: 160, r: 8$, ald $: 0, P / N: 1.68$

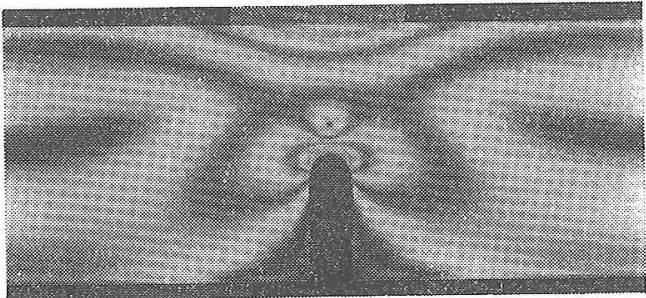

(h) 4-pt. $L: 160, l: 80, r: 8, w: 3.2$, ald: $1 / 2$, $P / N: 0.82$

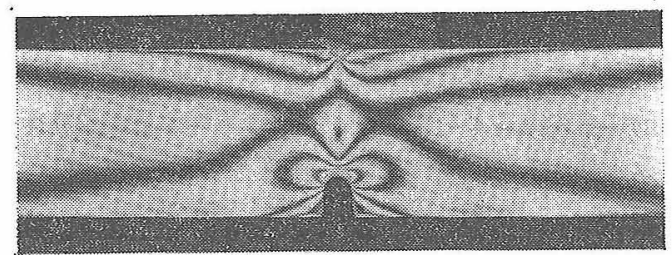

(i) 3-pt. $L: 160, r: 8$, w $: 3.2$, ald : $1 / 4, P / N: 0.59$

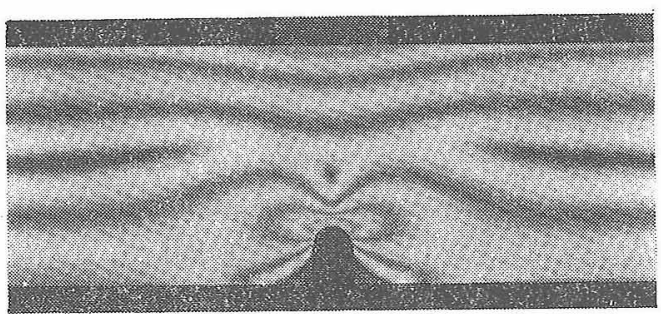

(j) 4-pt. $L: 160, l: 80, r: 8, w: 0.32, a / d: 1 / 4$, $P / N: 1.47$

Fig. 2. Stress distribution in specimens for various testing conditions : photoelastic photographs at 5 th order.

$L$ : Lower span length, $l:$ Upper span length, $r:$ Loading roll radius, $P:$ Load, $w$ : Notch width, $a$ : Notch depth, $d$ : Specimen height, $\mathrm{mm}, P / N$ : Load per one order of isochromatic lines, $\mathrm{kgf}$ 
Table 2. Properties of high strength ceramics (experimental values).

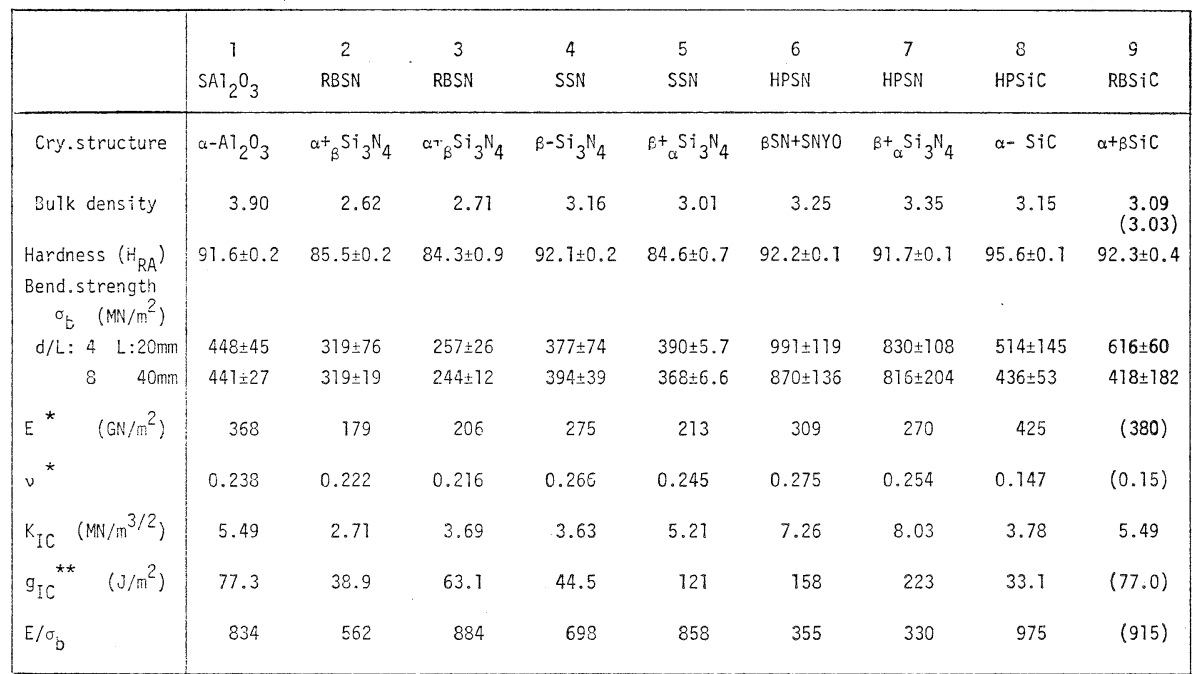

* Young's modulus and Poisson's ratio, measured at $10 \mathrm{MHz}$ ultrasonic by phase comparison method ** energy release ratio, $\left(K_{I C}{ }^{2} / E\right)\left(1-\nu^{2}\right)$

Table 3. The relation among equivalent crack length $\bar{a}$, notch depth $a$ and crack radius $\rho$.

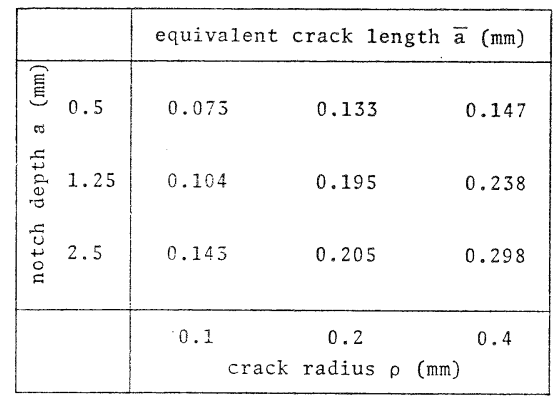

Simpson $^{3)}$ は, ノッチ先端に体積 0 , 先端半径 0 の先 端き裂を想定して，これらの全長を一つのき裂と見なす 条件を求めた Bowie の解析との比較をした.この条 件については, ノッチ深さ $a$ に対して先端き裂の長さ $\bar{a}$ がどの程度の大きさであれば $a+\bar{a}$ の長さのき裂と見 なし得るか， $\bar{a}$ の限界值として等価き裂長さを有限要素 法で求めた本間らの解析がある. 表 3 にその值を示し た.

破壞靶性を各材料の固有の性質と考えると，どのよう な試験条件でも同じ值を示すはずであるが，破壊試験に よる測定では試験ごとにき裂の進展開始状況が異なり， 值が変化する，SENB の曲げ試験においても，試験条 件に対して各材料が異なった效果を示し，ノッチ先端で の応力集中が緩和される条件では, 破壊荷重が増大して 見掛け上，破壊勒性が増大する.

理想的なき裂を，調節可能な方法でノッチ先端に一様 に作り，更にその長さを正確に知ることは困難であり， また微小き裂が多数発生した作用域（process zone）が 破壞き裂の前面にあり，その状態が材料によって異なる ものと仮定すれば5)，厳密に考えることは不要になる. したがってこの研究では, 破壊勒性の測定值が各材料に ついて安定して低い值で得られる試験条件の選定を一つ の目的とした.

また実験の際には，HPSN のようにダイヤモンド砥 粒に対しても難削性の材料について，ノッチ加工のとき にき裂の発生するのを避けるために, 経験上安全と考え られる切り込み深さ, 送り速度とし, ダイヤモンドソー の刃先は GC 砥石による修整及びドレッシングを繰り返 して行った.これによって Jones らの述べたノッチ加 工条件による $K_{\text {Ic }}$ の変化はあまり生じないものと考え られる ${ }^{6)}$.

各種 セラミックス材料の, 種々の試験条件に対する $K_{\mathrm{Ic}}$ の測定值の関係を図 3 に示した. 標準的なセラミッ クス材料である $\mathrm{SAl}_{2} \mathrm{O}_{3}$ では, 図 3 (a) に示すように測 定值のばらつきは少なく，ノッチ幅が大きい場合スパン $20 \mathrm{~mm}$ では $K_{\mathrm{Ic}}$ の増大が見られる. RBSN は窒化ケ イ素材料のうちで $\sigma_{\mathrm{b}}$ とともに $K_{\mathrm{Ic}}$ も低い. 試験条件 による $K_{\mathrm{Ic}}$ 值の変化は少なく，ノッチ深さなどの効果 は材料の種類によって異なる(図 3 (b), 図 3 (c)). SSN では $\sigma_{\mathrm{b}}$ とともに $K_{\mathrm{Ic}}$ も増大するが種類によって差が ある(図 $3(\mathrm{~d})$, 図 $3(\mathrm{e})$ ). HPSN は試験したセラミッ クス材料中で $\sigma_{\mathrm{b}}$ 及び $K_{\mathrm{Ic}}$ が最も高いが，測定值が分 散する傾向がある.これは燒結助剤及び微構造等につい て高度に改良されているために，製造条件の変動によっ て微構造の変化や不均質を生じた場合に，破壊強度が著 しく低下するためではないかと推定される（図 3 (f), 図 


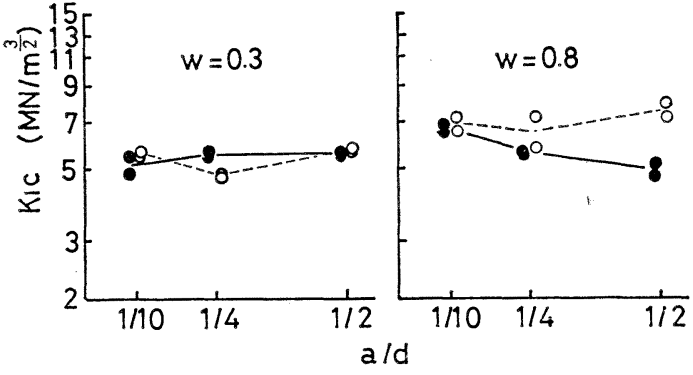

(a) $\mathrm{SAl}_{2} \mathrm{O}_{3}$

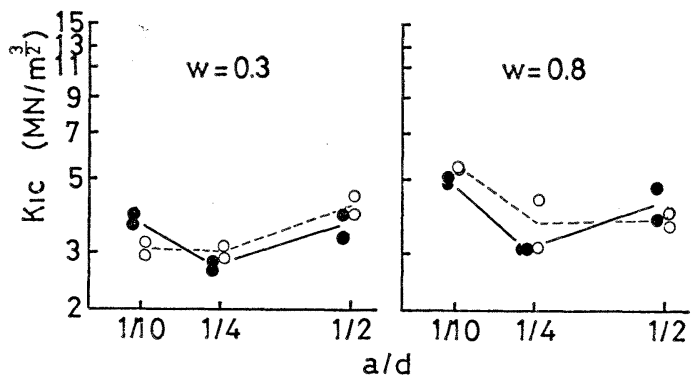

(b) $\mathrm{RBSN}$

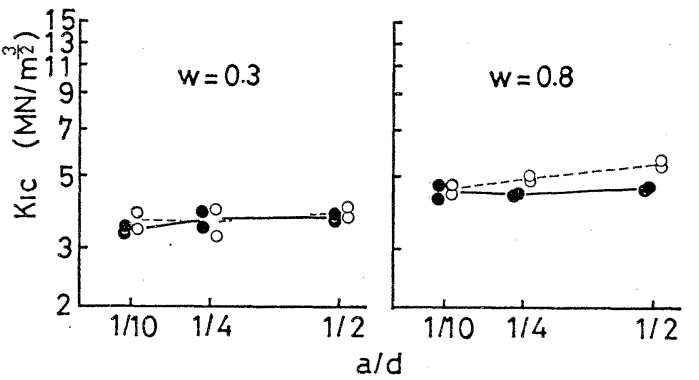

(c) RBSN

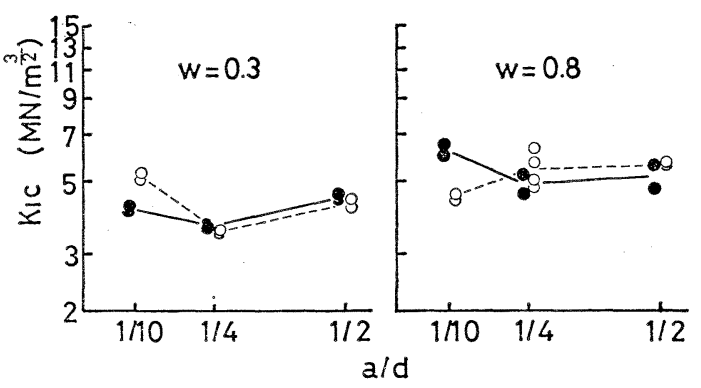

(d) $\mathrm{SSN}$

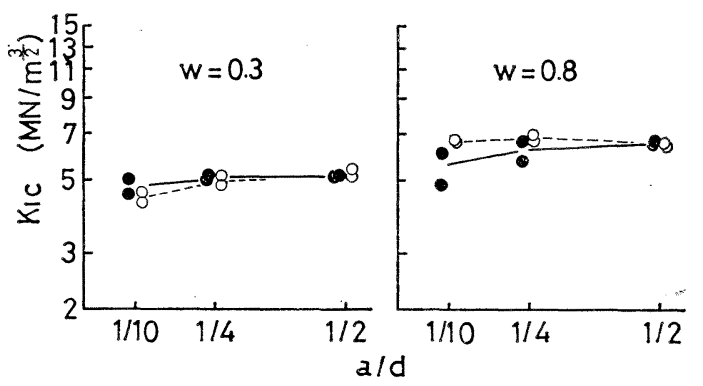

(e) $\mathrm{SSN}$

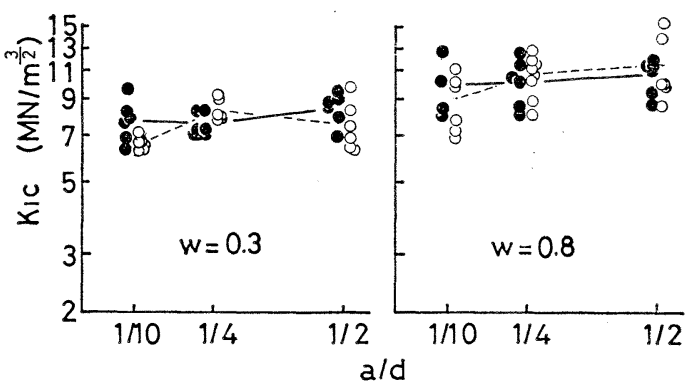

(f) HPSN

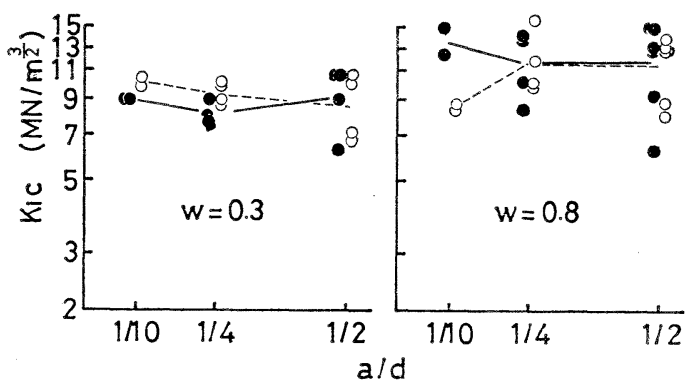

(g) HPSN

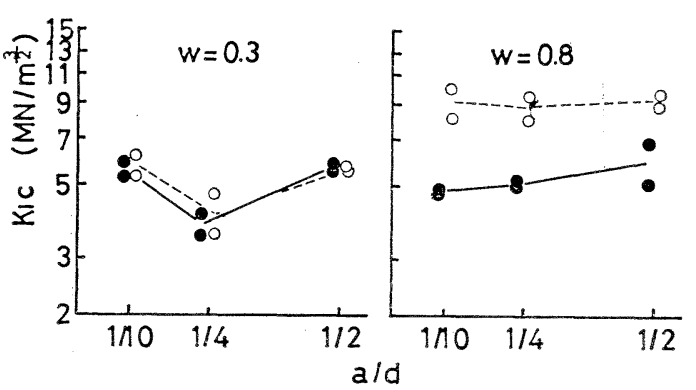

(h) HPSiC

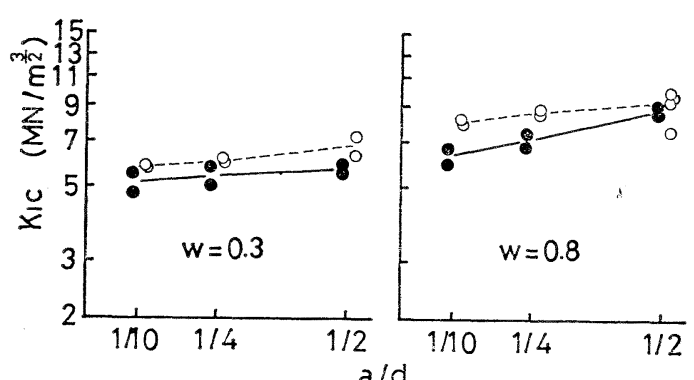

(i) $\mathrm{RBSiC}$

Fig. 3. Experimental fracture toughness of ceramics for various testing conditions. $L:$ Span length, $w$ : Notch width, $a$ : dotch depth, $d$ : Specimen height, $\mathrm{mm}$, Solid line : - L : $40 \mathrm{~mm}$, Dotted line : $\bigcirc--\bigcirc, L: 20 \mathrm{~mm}$ 


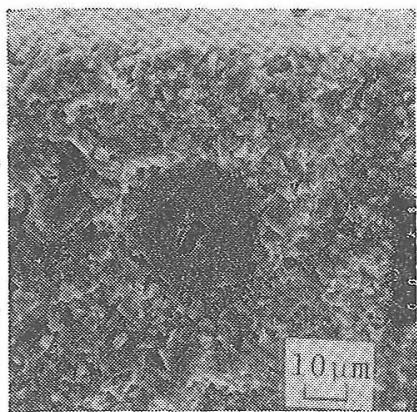

(a) $\mathrm{SAl}_{2} \mathrm{O}_{3}$

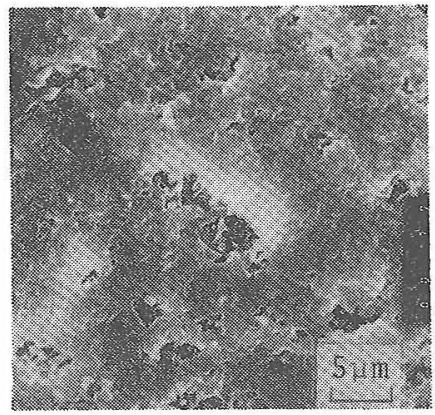

(b) RBSN
Fig. 4. Scanning electron micrographs of the fracture surface of ceramics by notched beam test. (a) $\mathrm{S}-\mathrm{Al}_{2} \mathrm{O}_{3}$; Small grain : Intergranular fracture, Large grain : Transgranular fracture, Pores: At grain boundary, (b) RBSN; Flat fracture surface, large connected and flat pore.
が最も低く，HPSiC が最高であるが。 この值の高い材料は拘束性の高い試験条 件では破壊応力が増大し，したがって

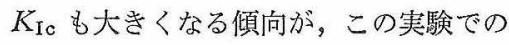
観察結果から認められた。ヤング率が材 料の密度と結合方式に依存するのに対し て，曲げ強さは材料の微構造，特に不均 質部分及び気孔等の欠宿や，結晶のへき 開性等の影響を受けるものと考えられる が，KIc の值に材料の弾性的性質が関係 する可能性があり，例えば $\mathrm{SiC}$ はヤン グ率が表 2 に示す材料中で最も高いのに 対して，そのポアソン比は他の材料と比 較して極めて低く，ひずみエネルギーが 集中しやすいものと推定される。図 5 は $3(\mathrm{~g}))$. HPSiC 及び RBSiC のいずれについても， ッチ幅が大きく，スパンが小さくて拘束性の高い条件 では $K_{\text {Ic }}$ が増大する.これは小さいき裂に対して鋭敏な $\mathrm{SiC}$ の特徵を示している(図 3 (h)，図 3 (i))。これらの 結果办ら各材料の $K_{\mathrm{Ic}}$ と試験条件の関係について， 大 パン $L$ ，ノッ千幅 $w$ 及びノッチ深さ $a$ を変動要因と して分散分析を行ったところ，検定では危険率 $5 \%$ 及び $1 \%$ に対して，ノッチ幅については全試料に有意差が認 められ，次いでノッチの深さが影響し，更に HPSiC な どにはスパンの効果が認められたで。

図 4 KSENB 曲げ試験の破面の例を示した。図 4 (a) 注 $\mathrm{SAl}_{2} \mathrm{O}_{3}$ の破面で，破壞の中心と見られる $100 \mu \mathrm{m}$ 平 方の部分である。上部の明るい部分がノッチ溝の先端部 分で，数 $\mu \mathrm{m}$ 程度の気孔が相当多数存在する. 破面に ほ直径 $2 \sim 5 \mu \mathrm{m}$ の微結晶と, $30 \mu \mathrm{m}$ 程度の板状結晶の 破面が見られる。図 4 (b) は RBSN の破面であるが， $33 \mu \mathrm{m}$ 平方の中に $1 \mu \mathrm{m}$ 以下の微気孔多数と， $3 \mu \mathrm{m}$ 程 度の偏平気孔が単独または連続して存在する状態を示し ている.

セラミックス材料では最もち密な HPSN でも $2 \mu \mathrm{m}$ 程度の気孔が点在し，破壞き裂への影響が推測される。

更にこれらのセラミックス材料の弾性定数と得られた $K_{\text {Ic }}$ の関係から，ひすみエネルギー解放率 $g_{\mathrm{Ic}}$ 老求めて, 破壊き裂の進展開始条件について検討した。平面ひずみ 条件では $g_{\mathrm{rc}}$ は次式で与えられる。

$$
g_{\mathrm{Ic}}=\left(K_{\mathrm{Ic}}{ }^{2} / E\right)\left(1-\nu^{2}\right)
$$

$K_{\mathrm{Ic}}, E$ 及びっの測定值から $g_{\mathrm{Ic}}$ を求めた結果を表 2 に示したが，HPSN では 160 220 J/m² であるのに 対して，HPSiC は $33 \mathrm{~J} / \mathrm{m}^{2}$ で，このことはき裂の進展 開始によって，蓄えられたひずみエネルギはあ喊少 しないので破壊が進みやすいことを示すものと考えられ る.

表 2 のヤング率と曲げ強さの比，E/ $\sigma_{\mathrm{b}}$ の值は HPSN
各種セラミックス材料の $g_{\mathrm{Ic}}$ と $E$ の関係を示したもの でおおむね材料の種類別に位置づけされる。

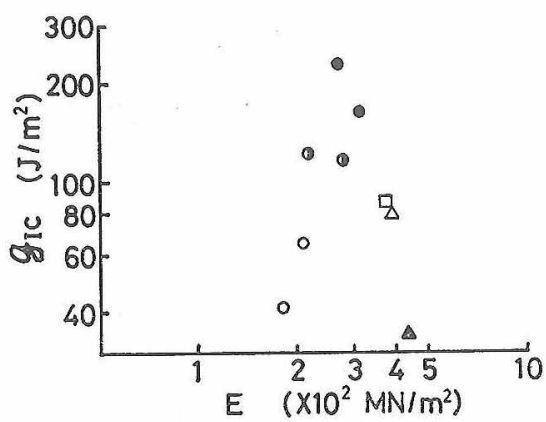

Fig. 5. Energy release ratio $\left(g_{\text {IC }}\right)$ and Young's moduli ( $E$ ) of ceramics.

$$
\begin{aligned}
& \square: \mathrm{S}-\mathrm{Al}_{2} \mathrm{O}_{3}, \mathrm{O}: \mathrm{RBSN}, \mathrm{SSN}, \\
& : \mathrm{HPSN}, \triangle: \mathrm{HPSiC}, \triangle: \mathrm{RBSiC}
\end{aligned}
$$

以上 $K_{\text {Ic }}$ の測定結果とこれに関連する材料の性質に ついて述べたが，この実験における $5 \times 5 \mathrm{~mm}$ 断面の試 験片による SENB 曲げ試験結果では，ノッチ幅 0.3 $\mathrm{mm}$ ，ノッチ深さは試験片高さの $1 / 4$ で，スパンが 40 $\mathrm{mm}$ の試駼条件が，各材料ともにやや $K_{\mathrm{Ic}}$ 值が低くな 可傾向を示し，妥当な測定条件に近いものと考えられ る.

\section{4. 総 括}

高強度セラミックス材料の SENB による 3 点曲げ試 験で破壊鞑性を測定し，光弾性実験による灾力分布及び エネルギー解放率等との関係について考察した。

（1） 2 次元光弾性実驗による応力分布の観察結果か らは，試験荷重が大きく，拘束性の高い曲げ試験条件で は，荷重点及び支持点に大きな圧縮応力が発生し，応力 こう配が大きくなることが認められて，不適当と考えら れる。

（2）ノッチの幅，媣さ及びスパンの大きさの勃果で 
破埕応力が增大する場合には， $K_{\mathrm{Ic}}$ の値も見掛け上増大 するが，この傾向は $E / \sigma_{\mathrm{b}}$ の值の大きい材料で高くな る.

(3) 断面 $5 \times 5 \mathrm{~mm}$ の試験片による SENB の曲げ 試験に括いては, ノッチ幅が小さく, 試験スパンが大 で，またノッチ深さが試験片高さの $1 / 4$ の場合に， $K_{\text {Ic }}$ 測定值が平均的低低く適当な条件と考えられる.

（4）ノッチドビームの曲げ試験による破壊勒性の測 定法は，セラミックス材料の特性を知るために有用であ り，また曲げ強さ試験法の延長上にある評価方法として 便宜な手段と考えられる.

\section{文献}

1) W.F. Brown and J.E. Srawley, Am. Test. Mater. Soc. Publ., 410, 1-129 (1966).

2）西田正孝, “応力集中”, 森北出版 (1973) p. 573.

3) L.A. Simpson, J. Am. Ceram. Soc., 51【4】 151-54 (1974).

4) 村上宏明, 本間恭二, 電気通信大学卒業論文, 1-33 (1980).

5) R.F. Pabst, J. Steeb and N. Clausen, "Fracture Mechanics of Ceramics" Vol. 4, Ed. by R.G. Bradt, D.P.H. Hasselman and F.F. Lange, Plenum Press (1977) p. 821-33.

6) R.L. Jones and D.J. Rowcliffe, J. Am. Ceram. Soc. Bull., 58, 1195 (1975).

7）松野外男, 若井史博, 昭和 55 年度空業協会東海支部研究 発表会前刷, 28-29 (1980).

論 文・Paper

\title{
ウルトラマリンに関連した反応の研究 \\ (カオリンからのウルトラマリン合成過程の研究（第1 報)）
}

\author{
石田信伍・藤村義和・藤吉加一*・若松 盈**

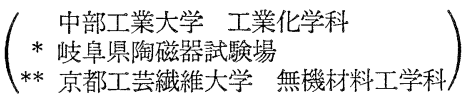

カオリン，炭酸ナトリウム，活性炭及び硫黄からウルトラマリンを合成する際の反応生成物をガ スクロマトグラフや化学分析で調べて, 硫黄が存在すれば $\mathrm{Na}_{2} \mathrm{CO}_{3}$ は $450^{\circ} \mathrm{C}$ でも容易に分解する こと, この結果生成した $\mathrm{Na}_{2} \mathrm{O}$ がカオリンと $\mathrm{Na}_{2} \mathrm{O}: \mathrm{Al}_{2} \mathrm{O}_{3} \cdot 2 \mathrm{SiO}_{2} \cdot n \mathrm{H}_{2} \mathrm{O}=1: 1$ の比率で反応す ることが分った. $\mathrm{Na}_{2} \mathrm{O}$ と $\mathrm{H}_{2} \mathrm{O}$ から同時的に生成した $\mathrm{NaOH}$ は次の反応式で硫黄と反応する.

$(4+2 \alpha) \mathrm{NaOH}+(3+\alpha x+x-\alpha) \mathrm{S} \rightarrow(1+\alpha) \mathrm{Na}_{2} \mathrm{~S}_{x}+(2-\alpha) \mathrm{H}_{2} \mathrm{~S}+\mathrm{Na}_{2} \mathrm{SO}_{4}+2 \alpha \mathrm{H}_{2} \mathrm{O}$

$500^{\circ} \mathrm{C}$ 以上では, $\mathrm{Na}_{2} \mathrm{SO}_{4}$ は活性炭によって $\mathrm{Na}_{2} \mathrm{~S}$ へ還元され, $\mathrm{CO}, \mathrm{COS}$ 及び $\mathrm{CO}_{2}$ が発生す る.

カオリン及び $\mathrm{Na}_{2} \mathrm{O}$ ・カオリンの表面積測定から, $\mathrm{Na}_{2} \mathrm{~S}_{x}$ は 7 層以上になっており, $\mathrm{Na}_{2} \mathrm{O} ・$ カオ リンの表面を広く覆っていることが推論された。

$\mathrm{CS}_{2}$ や $\mathrm{SO}_{2}$ を $\mathrm{Na}_{2} \mathrm{~S}_{x}$ と接触させると $\mathrm{S}_{3}{ }^{-}$(青色発色団) が生成した.この事実はウルトラマリ ン・ブルーの合成の際に $\mathrm{CS}_{2}$ や $\mathrm{SO}_{2}$ が重要な役割をすることを示唆する.

(1981 年 7 月 13 日受付)

\section{Studies of the Reactions Relating to Ultramarines (The Synthetic Process of Ultramarine from Kaolin, Part I)}
Shingo ISHIDA, Yoshikazu FUJIMURA, Kaichi FUJIYOSHI* and Mitsuru WAKAMATSU**

